\title{
Effect of Acidified Drinking Water on the Recovery of Salmonella enteritidis from Broiler Crops
}

Author(s)

Avila LAF de

Nascimento VP do

Canal CW

Salle CTP

Moraes HL de S

Centro de Diagnóstico e Pesquisa em Patologia Aviária (CDPA)

Faculdade de Veterinária da Universidade Federal do Rio Grande do Sul.

http://www.ufrgs.br/ppgcv/cdpa

\section{Mail Address}

UFRGS - CDPA

Luiz Antonio Faccenda de Avila

Av. Bento Gonçalves, 8824

Porto Alegre, RS

91.540-000

E-mail: luiz.favila@terra.com.br

\section{Keywords}

Broilers, citric acid, crop, cupric sulphate, $d-$ Limonene, lactic acid, organic acids, preslaughter feed withdrawal, Salmonella enteritidis.

\section{Acknowledgments}

We would like to thank Sadia S.A. and Btech Tecnologias Agropecuárias e Comércio Ltda for material and technical support, which made this work possible, as well as the staff from Laboratório Central da Sadia S.A. for the assistance during field trials.
Arrived: november/02

Approved: october/03

\section{ABSTRACT}

Crop is a known source of Salmonella contamination during broiler carcass processing. The effect of drinking water acidification by lactic acid or citric acid or a combination of those with cupric sulfate and dlimonene in the reduction of Salmonella Enteritidis (SE) recovered from the crop of broilers was evaluated. Treatments were administered during 8 hours of preslaughter fasting period (Experiments I and II) and during the last 32 hours of preslaughter (Experiment III). It was observed that acidification reduced water intake when treatments began at preslaughter feed withdrawal, and affected the possible reducing effect of these acids on SE recovering (Experiments I and II). Water intake during preslaughter feed withdrawal was not affected when treatment began 32 hours before slaughter (Experiment III). Treatments reduced SE recovering from crop $(p<0.05)$. In Experiment III, $0.470 \%$ of lactic acid reduced the number of recovered SE in $99 \%$. This study suggested that the addition of organic acids in the drinking water 24 hours before beginning the preslaughter feed withdrawal might reduce crop SE colonization and might be an important strategy to reduce SE contamination of broiler products during processing.

\section{INTRODUCTION}

Salmonella in birds is a major problem to international poultry industry because of its importance in diet intoxication, mainly caused by Salmonella enteritidis(SE) (Anônimo, 1988; Rodrigue et al., 1990; Humphrey, 1994; Poppe, 2000).

Broiler chickens are usually submitted to preslaughter feed withdrawal to promote gastro-intestinal emptying to reduce carcass contamination during slaughter. However, Humphrey et al. (1993) reported more SE in the crop of laying hens submitted to feed withdrawal than broilers fed ad libitum. Hargis et al. (1995) evaluated SE persistence in the crop and ceca of broilers experimentally inoculated, and concluded that the crop might be an important source of Salmonella contamination in broiler carcasses. Additionally, Ramirez et al. (1997) found that fasting increased Salmonellae incidence in broiler crops at preslaughter, evidencing the importance of such organ in the control of carcass bacterial contamination. In relation to number of Salmonella cells, the incidence of crop contamination may be increased up to five fold since feed withdrawal until slaughter (Corrier et al., 1999a). Recent studies showed that feed withdrawal causes changes in the crop, which are characterized by lactic acid reduction, $\mathrm{pH}$ increase and a consequent increase of Salmonella contamination (Corrier et al., 1999b). According to Barnhart et al. (1999), an association between citric acid and $d$-Limonene should be administered during preslaughter feed withdrawal to reduce the number of pathogens in the crop. Lactic acid given in drinking water 
during preslaughter feed withdrawal may reduce Salmonella and Campylobacterin the crop and probably broiler carcass contamination as well (Byrd et al., 2001). This work evaluated the effect of the acidification of drinking water, using lactic acid or citric acid or a combination of these with $d$-Limonene and cupric sulfate on SE recovery from the crop of artificially infected broilers.

\section{MATERIAL AND METHODS}

\section{Experiments}

Three experiments were carried out to test different concentrations of lactic acid (LACTO) or citric acid (CITRO) or a mix composed of $92.9 \%$ of lactic acid, $1.6 \%$ soluble $d$-Limonene and $5.5 \%$ of cupric sulphate (LACTOMIX) and a mix composed of $95.5 \%$ of citric acid, $1.0 \%$ of soluble $d$-Limonene and $3.5 \%$ of cupric sulphate (CITROMIX). $d$-Limonene was diluted in Tween-80 to a final concentration of $50 \%$. For each experiment one control group of birds received only pure water (additive-free water). Purity levels of lactic and citric acids were $85 \%$ and $50 \%$, respectively. Such percentages are related to the commercial product diluted in drinking water. Table 1 summarizes the intake period and concentrations of each experimental treatment.

\footnotetext{
Table 1 - Concentration of additives and intake period in each experiment. $^{1}$
}

\begin{tabular}{|c|c|c|c|}
\hline Treatments (\% & \%) Experiment & Experi & Expe \\
\hline $\mathrm{LACTO}^{5}$ & 0.470 & 0.350 & 0.470 \\
\hline LACTOMIX & 0.506 & - & - \\
\hline CITRO & & 0.800 & 0.800 \\
\hline CITROMIX & 0.800 & 0.400 & 0.400 \\
\hline Intake period & $\begin{array}{l}\text { Feed withdrawal } \\
\qquad(8 \mathrm{~h})\end{array}$ & $\begin{array}{l}\text { Feed withdrawal } \\
\qquad \text { I (8 h) }\end{array}$ & $\begin{array}{l}24 \text { hours before } \\
\text { feed withdrawal } \\
\text { and during feed } \\
\text { withdrawal ( } 8 \mathrm{~h} \text { ) }\end{array}$ \\
\hline \multicolumn{4}{|c|}{$\begin{array}{l}1-\text { All experiments had a control group of birds receiving additive-free } \\
\text { water. } 2-n=16 \text { repetitions of one bird per treatment. } 3-n=8 \text { repetitions } \\
\text { of one bird per treatment. } 4-n=8 \text { repetitions of two birds per treatment. } \\
5 \text {-LACTO - lactic acid; CITRO - citric acid; LACTOMIX }-92.9 \% \text { lactic } \\
\text { acid }+1.6 \% \text { soluble } d \text {-Limonene }+5,5 \% \text { of cupric sulphate; CITROMIX } \\
-95.5 \% \text { citric acid }+1.0 \% \text { of soluble d-Limonene }+3.5 \% \text { cupric sulphate. }\end{array}$} \\
\hline
\end{tabular}

In Experiments I and II, each bird was the experimental unit and it was used 16 and 8 repetitions per treatment. In Experiment III, there were 8 repetitions per treatment and a cage with two birds was used as experimental unit with individual evaluation.

\section{Birds}

Sex-mixed broilers were submitted to treatments from 40 to 44 days of age. All birds were originated from broiler chicken lots evaluated at 28 days of age for the absence of Salmonella spp. using drag-swab sampling. Broilers with thirty-six day-old were housed in a poultry house for 2 to 6 days to adapt to the drinker system. They were then transferred to an infection room and were kept for two more days or until the beginning of the experimental period. At the end of this period (4-8 days), birds were fed pellet diet without antibiotics or growth promoters. In the infection room, birds were placed in cages with wood floor covered with wood shavings as litter material.

\section{Inoculation}

Inoculums of nalidixic acid-resistant SE (Salmonella Enteritidis $N A^{r}$ ), kindly provided by Dr. Paul Barrow (AFRC Institute for Animal Health, Berkshire, UK), were prepared, with bacteria growing in tryptic soy broth (TSB) for 12 hours. The number of colony forming units (cfu) was determined by plate count of cultures serially diluted, using brilliant green agar plates with $40 \mathrm{mg}$. $\mathrm{mL}^{-1}$ of novobiocin and $25 \mathrm{mg} \cdot \mathrm{mL}^{-1}$ of nalidixic acid (BGN NO-NA).

Adapted birds were inoculated twice directly in the crop with $1 \mathrm{~mL}$ of inoculums containing $10^{8.96 \pm 0,22} \mathrm{cfu}$ of SE. The first inoculation was done when birds were transferred to the infection room (48 hours prior to feed withdrawal), and the second inoculation was performed at the beginning of the fasting period ( 8 hours before slaughter).

\section{Crop sampling and procedures}

Birds were taken from experimental cages and placed in boxes. They were kept in the boxes for 45 minutes to simulate the time spent with transportation from the poultry farm to the slaughterhouse. Afterwards, birds were slaughtered by cervical dislocation. Crops were aseptically removed, individually placed in Whirl-pac ${ }^{\mathrm{TM}}$ bags, and taken to the laboratory. Immediately after addition of $10 \mathrm{~mL}$ of sterile saline $(0.85 \% \mathrm{NaCl})$ to the bags, crops were homogenized in a Stomacher for 1 minute. Homogenate aliquots (0.5 $\mathrm{mL}$ ) were serially diluted in a 10-fold series using test tubes containing $4.5 \mathrm{~mL}$ of saline until a dilution rate of $1: 100,000$. One volume of $0.10 \mathrm{~mL}$ of each dilution and $0.50 \mathrm{~mL}$ of $1: 10$ dilute were plated in BGN NO-NA surface. Plates were incubated at $37^{\circ} \mathrm{C}$ for $24 \mathrm{~h}$ and the number of colony forming units was determined. 
Some colonies were confirmed by the biochemical tests of urease, lysine and triple sugar-iron-indole.

The $\mathrm{pH}$ of the homogenized crop was measured using an electronic potentiometer (Quimis) just after sampling for serial dilution.

\section{Statistical analysis}

Raw data of SE recovered from the crops were transformed into log 10 base and expressed in $\log _{10}$ of cfu. Transformed data were submitted to analysis of variance with the GLM procedure (SAS, 1998) in completely randomized blocks design, according to the following model: variable = overall mean for the variable + block effect + treatment effect + experimental error. Means of $\mathrm{pH}$ and cfu were compared by Tukey's test. Water intake (volume expressed as $\mathrm{mL} /$ bird during the preslaugther period) were compared using LS means procedure (SAS, 1998).

\section{RESULTS}

The $\mathrm{pH}$ values of plain water and freshly prepared acid solutions are presented in Table 2 .

\begin{tabular}{lc}
\hline Table $\mathbf{2}-\mathrm{pH}$ of water and freshly prepared acid solutions. \\
\hline & $\mathbf{p H}$ \\
\hline Treatments & 2.71 \\
& \\
$0.470 \%$ LACTO & 2.88 \\
$0.506 \%$ LACTOMIX & 3.11 \\
$0.350 \%$ LACTOMIX & 2.52 \\
$0.800 \%$ CITRO & 2.73 \\
$0.800 \%$ CITROMIX & 2.69 \\
$0.400 \%$ CITROMIX & 7.28 \\
\hline
\end{tabular}

\section{Experiment I}

$\mathrm{pH}$ and SE cfu recovered from the crop of broilers receiving drinking water treated with $0.470 \%$ LACTO, $0.506 \%$ LACTOMIX and $0.800 \%$ CITROMIX at preslaughter period were not different $(p>0.05)$ from control birds (Table 3). Water intake was higher $(p<0.05)$ in control broilers and those submitted to the $0.470 \%$ LACTO than in broilers given $0.506 \%$ LACTOMIX and $0.800 \%$ CITROMIX (Table 3 ).

\section{Experiment II}

$\mathrm{pH}$ and SE cfu recovered from the crop of broilers receiving drinking water treated with $0.350 \%$ LACTO and $0.400 \%$ CITROMIX during preslaughter feed withdrawal were not different $(p>0.05)$ from control. Broilers of the $0.800 \%$ CITRO treatment had reduced $(p<0.05)$ number of Salmonella cfu recovered from the crop compared to the control and to the $0.350 \%$ LACTO treatment. There were no statistical differences (p>0.05) in crop $\mathrm{pH}$ values among treatments. All experimental groups had lower $(p<0.05)$ water intake than the control group (Table 4).

\section{Experiment III}

In the $0.470 \%$ LACTO treatment, broilers had lower $(p<0.05)$ cfu of recovered SE than those of the control group and the $0.400 \%$ CITROMIX treatment. The treatments $0.800 \%$ CITRO and $0.400 \%$ CITROMIX reduced the number of recovered SE cfu compared to the control group, but there was no difference $(p>$ 0.05 ) between these treatments. Concerning crop pH of broilers from different treatments, no statistical differences $(p>0.05)$ were observed. Broilers treated with $0.800 \%$ CITRO had similar water intake to those treated with $0.400 \%$ CITROMIX, but had lower intake than the control group and the $0.470 \%$ LACTO treatment. During the preslaughter period, water intake was similar among broilers of different treatments (Table 5).

\section{DISCUSSION}

It is essential to maintain a Salmonella-free environment in poultry facilities to avoid broiler carcass contamination. However, the ability of this bacterium to infect many different animal species (Henzler \& Opitz, 1992; Kopanic et al., 1994; McAllister et al., 1994) increases the possibility of its persistence in the environment of poultry facilities and, consequently, the chance of broiler contamination even when they are originated from Salmonella-free breeders. In the Brazilian poultry industry, Salmonella monitoring in broiler houses is an increasing practice and special care during slaughtering have been adopted. This practice represents an important decision to obtain healthier products.

The contamination of final products is caused mainly by the slaughter of Salmonella-infected birds, which become a source of transmission to products that are being processed (Lillard, 1989). Many reports (Hargis et al., 1995; Ramirez et al., 1997; Corrier et al., 1999a) have described the importance of the broiler crop in carcass contamination, which is related to three basic facts: first, preslaughter feed withdrawal causes a reduction in the bacteria responsible for lactic acid production, which increases crop $\mathrm{pH}$ and proliferation of Enterobacteriaceae bacteria (Hinton et al., 2000); second, during the preslaughter period, litter intake 


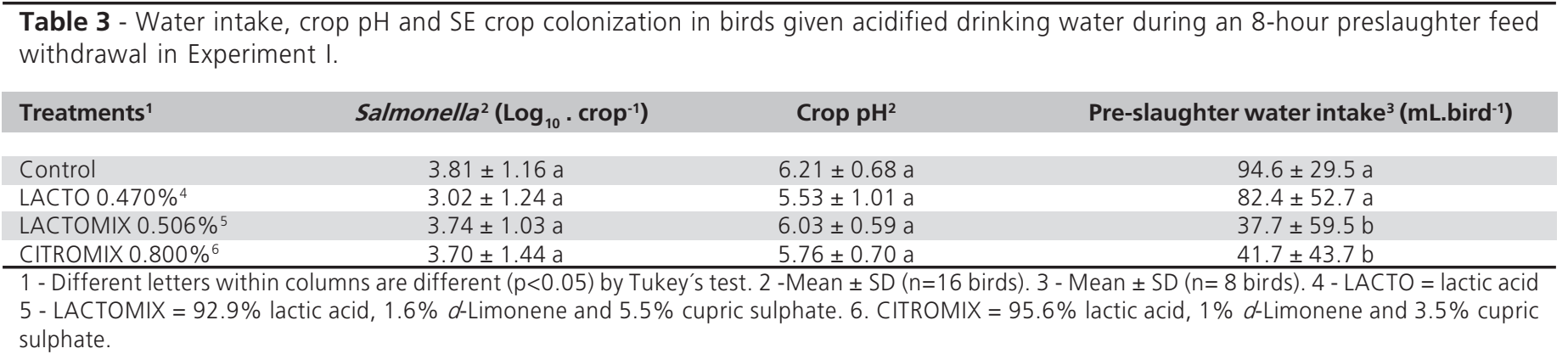

Table 4 - Water intake, crop pH and SE crop colonization in birds given acidified drinking water during an 8-hour preslaughter feed withdrawal in Experiment II.

\begin{tabular}{|c|c|c|c|}
\hline Treatments $^{1}$ & Salmonella ${ }^{2}\left(\log _{10} \cdot\right.$ crop $\left.^{-1}\right)$ & Crop $\mathrm{pH}^{2}$ & Preslaughter water intake ${ }^{3}\left(\mathrm{~mL}\right.$. bird $\left.^{-1}\right)$ \\
\hline Control & $3.79 \pm 0.43 b$ & $6.28 \pm 0.42 \mathrm{a}$ & $91.5 \pm 67.8 a$ \\
\hline LACTO $0.350 \%{ }^{4}$ & $3.93 \pm 0.68 b$ & $6.18 \pm 0.79 a$ & $25.3 \pm 27.7 b$ \\
\hline CITRO $0.800 \%^{5}$ & $2.67 \pm 0.70 a$ & $5.57 \pm 0.80 a$ & $39.8 \pm 30.8 b$ \\
\hline CITROMIX $0.400 \%^{6}$ & $3.47 \pm 0.86 \mathrm{ab}$ & $6.06 \pm 0.53 a$ & $35.9 \pm 24.7 b$ \\
\hline
\end{tabular}

Table 5 - Water intake, crop pH and SE crop colonization in birds given acidified drinking water during an 8-hour preslaughter feed withdrawal in Experiment III.

\begin{tabular}{|c|c|c|c|c|}
\hline Treatments $^{1}$ & Salmonella ${ }^{2} \log _{10} \cdot$ crop $\left.^{-1}\right)$ & Crop $\mathrm{pH}^{2}$ & 24 hours Water intake ${ }^{2,3}\left(\mathrm{~mL}^{\left.-b^{\prime} \mathrm{rdd}^{-1}\right)}\right.$ & 8 hours Water intake ${ }^{2,4}\left(\mathrm{~mL}^{-b^{\prime}}{ }^{-1}\right)$ \\
\hline Control & $4.17 \pm 0.53 c$ & $5.96 \pm 0.50 a$ & $305.2 \pm 98.6 a$ & $72.0 \pm 21.0 a$ \\
\hline $0.470 \%$ LACTO $^{5}$ & $2.17 \pm 1.07 \mathrm{a}$ & $5.47 \pm 0.74 a$ & $308.7 \pm 94.3 \mathrm{a}$ & $68.6 \pm 27.7 a$ \\
\hline $0.800 \%$ CITRO $^{6}$ & $2.56 \pm 0.95 a b$ & $5.48 \pm 0.70 a$ & $197.0 \pm 60.4 b$ & $77.0 \pm 25.5 a$ \\
\hline $0.400 \%$ CITROMIX $^{7}$ & $3.21 \pm 1.11 \mathrm{~b}$ & $5.39 \pm 0.75 a$ & $268.0 \pm 95.9 a b$ & $65.0 \pm 17.5 \mathrm{a}$ \\
\hline
\end{tabular}

increases (Corrier et al., 1999a), which might enhance the possibility of contamination; third, during the evisceration process, the crop might be disrupted (Hargis et al., 1995). The major part of the industrial processes used for crop collection promote carcass contamination due to crop disruption or leaking of the crop content. Thus, it is important to find a disinfectant to reduce Salmonella contamination in the crop immediately before slaughter and, consequently, the number of contaminated carcass (Barnhart et al., 1999).

Byrd et al. (2001) reported crop pH reduction in birds submitted to $0.5 \%$ acetic acid, $0.5 \%$ lactic acid and $0.5 \%$ formic acid treatments for 8 hours during preslaughter feed withdrawal. In our study there were no statistical differences in crop pH between treatments and control groups, although $\mathrm{pH}$ values showed a higher trend in control compared to the treated birds. In Byrd et al. (2001) study the data of five experiments were analyzed all together, resulting in 40 repetitions per treatment and, consequently, increasing analysis sensitivity. In the present study, statistical analysis was carried out for each experiment independently, because there were different treatments in each experiment, and thus, the number of repetitions was smaller. Also, Byrd et al. (2001) measured pH in situ, through a crop incision where electrode was placed in direct contact with the mucosa. In our work, $\mathrm{pH}$ was determined in the crop homogenized with saline, and homogenization might have released intracellular buffering substances, which might have affected the results.

The low intake of acidified water during preslaughter feed withdrawal has been considered a disadvantage in using such substances for crop decontamination. In Experiment $\mathrm{l}$, the treatments $0.506 \%$ LACTOMIX and $0.800 \%$ CITROMIX showed reduced water intake. In Experiment II, lactic acid concentration in LACTO and CITROMIX treatments was reduced trying to normalize 
water intake during preslaughter, similarly to Byrd et al. (2001), who reduced lactic acid from one experiment to the other and found no difference in water intake, when birds treated with $0.44 \%$ lactic acid were compared with control. This approach resulted in no benefit in our study, because water intake was reduced in treated groups. Specifically, lactic acid decreased water intake and their bactericidal effect was reduced when data of Experiments I and II were compared.

In Experiment III, another strategy was used to normalize water intake at pre-slaughter fasting. Treatments began before preslaughter fasting, when birds were still being fed and thus, when water requirement was still higher. Therefore, acidified water was administered 24 hours earlier than the beginning of the fasting period. This strategy had a good result because there was no difference in water intake between treated and control birds. Barnhart et al. (1999) were also interested in avoiding the reduction in water intake due to treatment. They offered a combination of citric acid and $d$-Limonene in gelatin capsules, and crop SE was reduced when capsules were fed in the last 45 minutes of preslaughter feed withdrawal.

The reduced water intake during the preslaughter feed withdrawal and the consequent decrease in acid intake reduced the effect that the acids might have in the number of viable SE in the crop. In the three experiments, the reduced water intake was associated to the lack of difference in the number of SE recovered from the crop between the treated and control groups. On the other hand, when water intake was not affected, differences in number of recovered SE were seen, except for Experiment I, when all data from treated and control groups were analyzed together. In this case, birds submitted to the $0.470 \%$ LACTO treatment had water intake similar to control birds, but there were no differences in the number of recovered Salmonella. However, when the $0.506 \%$ LACTOMIX and the $0.800 \%$ CITROMIX treatments and the control group were compared only to the $0.470 \%$ LACTO treatment, the number of recovered Salmonella was reduced $(p<0.01)$.

Recent in vitro experiment of our laboratory (unpublished data) indicated that the addition of $d$ Limonene and cupric sulfate to citric acid increased the ability to reduce SE recovery. Results from Experiments I and II demonstrated that the addition of $d$-Limonene and cupric sulfate to citric and lactic acids (LACTOMIX and (ITROMIX) did not show similar findings than the in vitro study. In Experiment III, even with half concentration of CITROMIX, water intake was normal and was observed a reduction in the number of SE recovered from the crop. Thus, we can conclude that the amplification effect of $d$-Limonene and cupric acid addition, as seen in vitro, could not be repeated due to the reduction in water intake and the increased effect of $0.470 \%$ LACTO, which reduced the recovery of SE in the crop in all the experiments. These findings confirm the benefit of starting the administration of acids 24 hours before the beginning of the preslaughter feed withdrawal.

The $0.470 \%$ LACTO treatment, administered 24 hours before starting the preslaughter feed withdrawal, reduced SE recovery from the crop in $2 \log _{10}$ (from 4.17 to $\left.2.17 \log _{10}\right)$, which means a great reduction in the number of this bacterium. Such reduction in the number of contaminant cells might also reduce final contamination by the end of the industrialization process.

In conclusion, the findings of this study suggested that the use of lactic or citric acid in drinking water during preslaughter feed withdrawal has a decreasing effect on SE recovery from the crop. The addition of acids, if started 24 hours before the beginning of preslaughter feed withdrawal, might help to reduce crop contamination by SE.

\section{REFERENCES}

Anônimo. Salmonellosis control: the role of animal and product hygiene. Relatório do Comitê de Especialistas da Organização Mundial da Saúde. Série de Relatórios Técnicos número 774. Genebra. Suíça. 1988.

Barnhart ET, Sarlin LL, Caldwell DJ, Byrd JA, Corrier DE, Hargis BM. Evaluation of potencial disinfectants for preslaughter broiler crop decontamination. Poultry Science 1999; 78:32-37.

Byrd JA, Hargis BM, Caldwell DJ, Bailey RH, Herron KL, McReynolds JL, Brewers RL, Anderson RC, Bischoff KM, Callaway TR, Kubena LF. Effect of lactic acid administration in the drinking water during preslaughter feed withdrawal on Salmonella and Campylobacter contamination of broilers. Poultry Science $2001 ; 80: 278-283$.

Corrier DE, Byrd JA, Hargis BM, Hume ME, Bailey RH Stanker LH. Presence of Salmonella in the crop and ceca of broiler chickens before and after preslaughter feed withdrawal. Poultry Science 1999a; 78:45-49

Corrier DE, Byrd JA, Hargis BM, Hume ME, Bailey RH, Stanker LH. Survival of Salmonella in the crop contents of market-age broilers during feed withdrawal. Avian Diseases 1999b; 43:453-460.

Hargis BM, Caldwell DJ, Brewer RL, Corrier DE, Deloach JR. Evaluation of the chicken crop as a source of Salmonella contamination for broiler carcasses. Poultry Science 1995; 74:1548-1552. 
Henzler DJ, Opitz HM. The role of mice in the epizootiology of Salmonella enteritidis infection on chicken layer farm. Avian Diseases 1992; 36:625-631.

Hinton Jr A, Buhr RJ, Ingram KD. Physical, chemical, and microbiological changes in the crop of broiler chickens subjected to incremental feed withdrawal. Poultry Science 2000; 79:212218.

Humphrey TJ, Baskerville A, Whitehead A, Rowe B, Henley A. Influence of feeding patterns on artificial infection of laying hens with Salmonella enteritidis phage type 4. The Veterinary Record 1993; 132:407-409.

Humphrey TJ. Contamination of egg shell and contents with Salmonella enteritidis: a review. International Journal of Food Microbiology 1994, 21:31-40.

Kopanic RJ Jr, Sheldon BW, Wright CG. Cockroaches as vectors of Salmonella: Laboratory and field trials. Journal of Food Protection 1994; 57:125-132.

Lillard HS. Factors affecting the persistence of Salmonella during the processing of poultry. Journal of Food Protection 1989; 52:829-832.

McAllister JC, Steelman CD, Skeeles JK. Reservoir competence of the lesser mealworm (Coleptera: Tenebrionidae) for Salmonella Typhimurium (Eubacteriales: Enterobacteriaceae). Journal of Medical Entomology 1994; 31:369-372.

Poppe C. Salmonella infections in domestic fowl. In: C. Wray \& A. Wray (ed.). Salmonella in Domestic Animals. Wallingford: CABI Publishing. 2000.

Ramirez GA, Sarlin LL, Caldwell DJ, Yezak CR Jr, Hume ME, Corrier $D E$, Deloach JR, Hargis BM. Effect of feed withdrawal on the incidence of Salmonella in the crops and ceca of market age broiler chickens. Poultry Science 1997; 76:654-656.

Rodrigue, DC, Tauxe RV, Rowe B. International increase in Salmonella enteritidis: a new pandemic? Epidemiology and Infection 1990; 105:21-27.

SAS Institute. Statistical Analysis System. User Guide. SAS Institute Inc. Cary, NC. 1998. 